\title{
The Effects of Altered Nutritional Status upon Insulin-Like Growth Factors and their Binding Proteins in Neonatal Rats ${ }^{1}$
}

\author{
ANTHONY PHILIPPS, KATARINA DRAKENBERG, BENGT PERSSON, BARBRO SJÖGREN, \\ ANN CHRISTINE EKLÖF, KERSTIN HALL, AND VICKI SARA \\ Department of Pediatrics, University of Connecticut Health Center [A.P.], Farmington, CT 06032; and the \\ Departments of Pediatrics [A.C.E., B.P.], Pathology [K.D., V.S., B.S.] and Endocrinology [K.H.], Karolinska \\ Institute, Stockholm, Sweden
}

\begin{abstract}
To investigate the role of nutrition in the regulation of IGFs during the perinatal period, 10-d-old rats were infused intravenously with various concentrations of nutrients for $24 \mathrm{~h}$. Breast-fed litter mates served as controls. The effect of caloric intake on concentrations of IGF-I and IGF-II as well as IGF-binding proteins in serum, liver, and brain of neonatal rats was studied. A total of 45 rats from 10 litters was infused with solutions ranging from a caloric intake of 0 (saline) to $75 \%$ (glucose, amino acids, and lipids) of the estimated intake of control rats. In serum, both IGF-I and -II concentrations fell markedly in response to fasting. Serum IGF-II levels were linearly related to caloric intake in the pooled data from all groups. Concentrations of IGF-II, but not IGF-I, in liver and brain were depressed by caloric restriction. In contrast to the fall in IGF concentrations, activity of IGF-associated binding proteins rose in serum and in liver cytosol 2- to 4-fold in response to decreased nutrient intake. In serum, but not liver, the rise in binding protein activity was inversely related to caloric intake. In liver cytosol, but not serum, the rise in binding protein activity was inversely related to total serum amino acid concentration. Thus, IGF concentrations in preweanling rats change in response to alterations of nutrient intake. The fasting induced decrements in IGF levels, as well as the elevations in IGF-associated binding protein activity, may serve as a protective mechanism to depress growth in times of caloric restriction. (Pediatr Res 26: 128-134, 1989)
\end{abstract}

\section{Abbreviations}

CON, control

SAL, normal saline

GLU, glucose

GA, glucose and amino acids

GAL, glucose, amino acids, and lipid

RRA, radioreceptor assay

HSA, human serum albumin

GH, growth hormone

Received January 18, 1989; accepted April 14, 1989.

Correspondence and reprint requests Dr. Anthony F. Philipps, Department of Pediatrics, University of Arizona Health Sciences Center, 1501 North Campbell Avenue, Tucson, AZ 85724 .

Supported by grants from the University of Connecticut Research Foundation, the National Institutes of Health (R-01-DK26067), the Swedish Medical Research Council, the Expressen Prenatal Fund, the Swedish Diabetes Association and the Bergvalls Foundation. AFP was also supported by a research fellowship from the Fogarty International Center, National Institutes of Health (1-F06-TW01050).

${ }^{1}$ Parts of this work were presented in preliminary form at the Society for Pediatric Research, 1988 and he European Society for Pediatric Research, 1988.
Somatomedins, or IGF, comprise a group of peptides having both mitogenic and insulin-like metabolic effects in a variety of mammalian cell types in vitro $(1,2)$. Because of the extremely rapid growth rate of the mammalian fetus and neonate, attention has recently focused upon the somatomedins as possible regulators of fetal somatic and organ growth $(3,4)$. Little is known, however, about those factors that alter cellular synthesis of somatomedins in the perinatal period. As in the adult (5), in vitro evidence suggests that substrate availability may be of importance in regulating somatomedin secretion (4).

During the perinatal period, developmental changes in somatomedins have been studied most extensively in the rat $(4,6)$. In this species, during fetal life and before weaning ( 21 days), the predominant somatomedin in blood and tissues is an IGF-II (previously known as multiplication-stimulating activity) which shares close homology with human IGF-II $(1,2,6)$. After weaning, the predominant somatomedin species is an IGF-I similar to human IGF-I $(3,4,7)$. Unlike the adult, GH does not seem to be of importance in IGF regulation in the preweanling rat (8). For these reasons a study was performed to investigate the role of nutrition in the regulation of IGF-I and -II synthesis during the perinatal period in the rat. In addition, because of the difficulty in measurement of somatomedin activity due to the presence of binding proteins in most biologic fluids (9), care was taken to separate binding proteins from IGF-I and -II before assay.

\section{MATERIALS AND METHODS}

Surgical preparation. Male Sprague-Dawley rats from 10 litters between 10 and $12 \mathrm{~d}$ postnatal age were studied. Polyethylene chloride catheters were implanted in the right external jugular vein under ether anesthesia. Catheters were secured with a 4-0 silk ligature and a small section of surgical plastic tape. Postoperatively, animals were housed in individual cushioned trays within a humidified Armstrong "Care-Ette" incubator (Ohio Chemical, Madison, WI) at $29^{\circ} \mathrm{C}$ ambient temperature. Litter mates were obtained as $\mathrm{CON}$ and were subjected to similar anesthesia and surgical incisions without catheterization. After recovery these CON animals were then replaced with their respective dams. These studies were approved by the Animal Care Committees of the Karolinska Institute and The University of Connecticut Health Center.

Experimental protocol. After a 2-h postoperative recovery period, catheterized rats were begun on an iv infusion of one of four nutrient solutions of different composition: SAL, GLU, GA, and GAL. No enteral nutrition was provided. Solutions for infusion were made daily under sterile conditions from the following stock solutions: amino acids as Vamin $14 \mathrm{~g} \mathrm{~N} / 100 \mathrm{~mL}$ 
(Kabi Vitrum, Stockholm, Sweden), lipid as Intralipid $10 \mathrm{~g} / 100$ $\mathrm{mL}$ (Kabi Vitrum), and glucose $50 \%$ in sterile water. Final volume of delivery was adjusted to $5.2 \mathrm{~mL}$ using sterile water. The infusions were given at rates between $180-230 \mu \mathrm{L} / \mathrm{h}$ via a precalibrated electric syringe pump (Braun-Melsungen AG, Melsungen, West Germany) to achieve a fluid intake of approximately $200 \mu \mathrm{L} / \mathrm{g} / \mathrm{d}$. Neonatal rats received tactile stimulation three to four times per day, both to mimic maternal handling and to stimulate micturition. $\mathrm{CON}$ litter mates were allowed to nurse ad libitum with their dams until the conclusion of the 24$\mathrm{h}$ study period. Thus, for the $24-\mathrm{h}$ study period, infused rats were to receive intakes of nutrients and calories as in Table 1 .

At the conclusion of the experimental period, $20 \mu \mathrm{l}$ of blood were drawn via tail section in both infused rats and their milk fed controls and analyzed for plasma glucose concentration and hematocrit. All rats were then anesthetized with ether and exsanguinated by cardiac puncture. The blood obtained was allowed to coagulate at room temperature. Serum was removed and stored at $-20^{\circ} \mathrm{C}$ for later assay for IGF and amino acids. Livers and brains were removed, blotted, weighed, and then stored at $-80^{\circ} \mathrm{C}$ for later analysis.

Biochemical Methods. RIA-IGF-I. IGF-I RIA was performed using purified human IGF-I and $\left.{ }^{125} \mathrm{I}\right]-$ IGF-I as standard and tracer-hormone, respectively, as previously described $(1,10)$. Results are expressed as $\mathrm{ng} / \mathrm{mL}$. The standard currently in use in our laboratory is a biosynthetic IGF-I (Kabi Gen AB, Stockholm, Sweden) and has an activity of approximately $180 \mathrm{ng}$ IGFI/U RIA-IGF-1 activity, where $1 \mathrm{U}$ of activity is arbitrarily defined as that activity present in $1 \mathrm{ml}$ of a standard human serum. The term "IGF-I concentration" will be used to denote IGF-I assayed from acidified chromatographed fractions.

$R R A-I G F-I I$. Membranes were prepared using the method of Marshall et al. (11) from the livers of 60- to 90-d-old male Sprague-Dawley rats. Studies regarding displacement of $\left[{ }^{125} \mathrm{I}\right]-$ IGF-II from rat liver membranes were then performed. In comparison to purified human IGF-II (kindly supplied by G. Enberg, M.D., Karolinska Institute, Stockholm, Sweden), purified human IGF-I exhibited approximately $1 \%$ cross-reactivity. Human insulin did not cross-react with IGF-II in this assay. Incubation with multiplication-stimulating activity (Collaborative Research, Waltham, MA) produced displacement similar to that of IGF-II. Due to a paucity of purified IGF-II for standards, serial dilutions of an aliquot from a pool of standard human serum were used in the standard curve, and thus, results are expressed as $U$ or $\mathrm{mU} / \mathrm{mL}$ or $\mathrm{g}$ wet tissue wt. The standard serum was calibrated against purified IGF-II and contained $900 \mathrm{ng}$ IGF-II/U IGF-2 activity, where $1 \mathrm{U}$ of activity is again defined as that present in $1 \mathrm{~mL}$ of serum. Thus $1 \mathrm{mU} / \mathrm{mL}$ represents $0.9 \mathrm{ng} / \mathrm{ml}$ IGF-II concentration. Least detectable dose was approximately $20 \mathrm{mU} /$ $\mathrm{ml}$ and inter- and intraassay coefficients of variation were 7.6 and $11.6 \%$, respectively. The term "IGF-II concentration" will be used to denote IGF-II assayed from acidified chromatographed fractions and "RRA activity" for that activity assayed using the IGF-II RRA from whole serum, cytosol, or binding protein fractions from column chromatography. In these studies, the majority of RRA activity noted from whole serum and

Table 1. Constituents of Infusates in 10-d-old rats

\begin{tabular}{lccccc}
\hline & $\begin{array}{c}\text { Fluid } \\
\text { volume } \\
(\mathrm{mI})\end{array}$ & $\begin{array}{c}\text { Carbohydrate } \\
(\mathrm{g})\end{array}$ & $\begin{array}{c}\text { Lipid } \\
(\mathrm{g})\end{array}$ & $\begin{array}{c}\text { Amino } \\
\text { acid } \\
(\mathrm{g})\end{array}$ & $\begin{array}{c}\text { Total } \\
\text { cal }\end{array}$ \\
\hline $\mathrm{CON}^{*}$ & 5.2 & 0.10 & 0.60 & 0.35 & 7.2 \\
$\mathrm{SAL}$ & 5.2 & 0.00 & 0.00 & 0.00 & 0.0 \\
$\mathrm{GLU}$ & 5.2 & 0.63 & 0.00 & 0.00 & 2.5 \\
$\mathrm{GA}$ & 5.2 & 0.10 & 0.00 & 0.26 & 1.4 \\
$\mathrm{GAL}$ & 5.2 & 0.10 & 0.40 & 0.26 & 5.2 \\
\hline
\end{tabular}

* Approximate volume and nutrient concentration from Reference cytosol specimens was due to binding proteins, and thus represents a crude estimate of binding protein activity.

Somatomedin Separation. Sera. All whole, untreated sera specimens were assayed for RRA-activity using the IGF-II RRA. IGF-I and IGF-II in sera specimens were then dissociated from binding proteins using acid gel chromatography. Approximately $300-400 \mu \mathrm{L}$ of serum obtained by pooling samples from two to three animals was acidified to $2 \mathrm{M}$ with acetic acid and incubated overnight at $+4^{\circ} \mathrm{C}$. The sample was then chromatographed at $+4^{\circ} \mathrm{C}$ over a $48 \times 1.0 \mathrm{~cm}$ Sephadex G-50 (Pharmacia Fine Chemicals, Piscataway, NJ) column equilibrated in $0.1 \mathrm{M}$ acetic acid at a constant flow rate of $2.0 \mathrm{~mL} / \mathrm{h}$. Fractions from the column $(1.5 \mathrm{~mL} /$ fraction) were lyophilized, reconstituted in 50 $\mathrm{mM}$ Tris (pH 7.40 at $21^{\circ} \mathrm{C}$ )- $1 \%$ HSA buffer, and assayed for RIA-IGF-I and RRA-IGF-II concentrations. When tracer [ $\left.{ }^{125} \mathrm{I}\right]-$ IGF-II was preincubated with serum and then acidified using this method, recovery of tracer hormone was $93 \%$. Results are expressed as ng (IGF-I) or mU (IGF-II) per $\mathrm{ml}$ serum.

Cytosol. Cytosols from liver and brain specimens were obtained using the method of Sara et al. (12). Tissue was minced in $5 \mathrm{ml}$ (per $\mathrm{g}$ tissue) of a solution of $50 \mathrm{mM}$ Tris $\mathrm{HCl}$ and 0.2 $\mathrm{mM}$ phenylmethyl sulfonylfluoride (Boehringer-Mannheim, Inc, Penzberg, W. Germany), using a Polytron tissue homogenizer (Brinkman Instruments, Westbury, NY). The homogenate was then centrifuged at $50000 \times g$ for $30 \mathrm{~min}$ and the supernatant (cytosol) removed and then stored at $-80^{\circ} \mathrm{C}$ for later assay. All cytosol specimens were assayed prior to chromatography for whole cytosol RRA using the RRA-IGF-II. As with the sera specimens, IGF-I and -II in cytosols were dissociated from binding proteins during the acidification process. Approximately 10 $\mathrm{ml}$ of cytosol obtained as a pool of two to three samples was dialyzed (Spectrapor no. 6 dialysis membrane, Spectrum Medical Industries, Los Angeles, CA) against $0.1 \mathrm{M}$ acetic acid for $48 \mathrm{~h}$ at $+4^{\circ} \mathrm{C}$. The supernatant was removed after centrifugation and concentrated to $1 \mathrm{ml}$ using a rotary evaporator. The concentrated specimen was then chromatographed using a $40 \times 1 \mathrm{~cm}$ Sephadex G-50 column equilibrated with $0.1 \mathrm{M}$ acetic acid. Fractions were subsequently lyophilized, reconstituted in assay buffer, and assayed for both RIA-IGF-I and RRA-IGF-II concentrations. Recovery of a biosynthetic preparation of IGF-I (kindly supplied by L. Fryklund, Kabi Vitrum AB) from acidified cytosol was $72 \%$.

Calculation of Somatomedin Activity (Fig. 1). All Sephadex G-50 columns used were calibrated with Blue Dextran, cobalt chloride, and [ ${ }^{125}$ I]-IGF-II. Peak somatomedin activity was de-

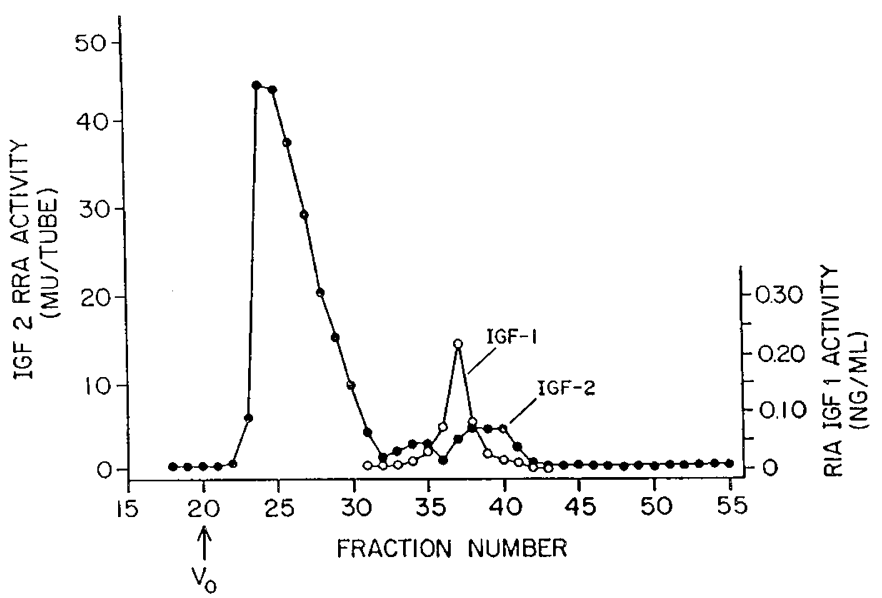

Fig. 1. Typical gel chromatograph of control 10-d-old rat serum. Serum was incubated in $2 \mathrm{M}$ acetic acid and then chromatographed using G-50 Sephadex, 0.1 M acetic acid. Selected fractions were lyophilized, reconstituted in assay buffer, and analyzed for concentrations of RIA-IGF-I (open circles) and RRA-IGF-II (closed circles). The large high mol wt fraction represents IGF binding proteins. 
tected at approximately $50 \%$ of the column vol with the total peak found between 30 and $70 \%$ of the column vol. Therefore, IGF-I and -II concentrations were defined as the total radioimmunoassayable or radioreceptorassayable activity present in these fractions, expressed as either ng (IGF-I) or mU (IGFII) per g tissue wet wt.

Binding Protein Activity. That portion of the column fractions from $0-30 \%$ exhibited a peak of RRA activity in serum and cytosol, presumably related to the ability of binding proteins to compete with receptor for [ $\left.{ }^{125} \mathrm{I}\right]-\mathrm{IGF}-\mathrm{II}$ binding. To test this assumption, liver cytosol was preincubated with [ $\left.{ }^{125} \mathrm{I}\right]-\mathrm{IGF}-\mathrm{II}$ for $2 \mathrm{~h}$ at $+4^{\circ} \mathrm{C}$ and then chromatographed over a $40 \times 1 \mathrm{~cm} \mathrm{G-50}$ Sephadex column equilibrated with $50 \mathrm{mM}$ Tris- $0.2 \%$ HSA. Flow rate and fraction volume were as in the previous studies. Fractions were then counted in a $\gamma$-counter and the results plotted as fraction vol versus $\mathrm{cpm}$ and compared to the elution pattern of [ $\left.{ }^{125} \mathrm{I}\right]-\mathrm{IGF}-2$ alone. Similar chromatograms were performed on a lyophilized aliquot of the cytosol reconstituted in Tris- $-0.2 \%$ HSA and also on another aliquot dialyzed against 0.1 $M$ acetic acid, lyophilized, and then reconstituted in buffer. In further studies characterizing liver cytosol and serum binding proteins, similar schemata were used with chromatography performed on a $90 \times 1.9 \mathrm{~cm} \mathrm{G}-200$ Sephadex column with $50 \mathrm{mM}$ Tris- $0.2 \%$ HSA. To compare chromatographs, results were converted to $\mathrm{cpm}$ per fraction as a percent of total counts added to the column $(\% \mathrm{cpm})$.

Miscellaneous. Glucose concentrations in plasma were measured using a glucose oxidase method (Beckman). Hb concentration was measured colorimetrically and protein concentration was determined using the method of Lowry et al. (13). The formula derived by D'Ercole et al. (14) was used to estimate the percentage blood concentration in cytosol samples of liver and brain. Some blood contamination of liver (but not brain) cytosol specimens was observed and could theoretically have accounted for up to $14 \%$ of the RRA activity observed in control livers. However, because of the relatively larger increase in RRA activity in liver cytosol versus serum in the experimental groups, maximal contamination from serum represented only $5 \%$ of the total RRA activity. In selected cases, plasma samples from four to six animals from each group were assayed individually for the con- centrations of 20 amino acids using a Waters Liquid Chromatography Amino Acid Analyzer (Waters Associates, Milford, MA).

Statistical analysis. All results are expressed as mean \pm SEM. Statistical significance was assessed using ANOVA and the unpaired Student's $t$ test. Linear regression analysis was performed using the least squares method.

\section{RESULTS}

General metabolic parameters. A total of 45 rats was infused during the 24-h study period (Table 2). A total of 17 wt- and sex-matched litter mates served as the CON. No differences were observed in age or wt at the time of study (Table 2). At the conclusion of the study, all infused rats appeared vigorous and active. Plasma glucose concentration in the SAL infused group was $3.78 \pm 0.44 \mathrm{mM}(54 \pm 6 \%$ of the CON concentration, $p<$ $0.05)$ and in the GLU was $8.22 \pm 0.89 \mathrm{mM}(118 \pm 13 \%$ of control, $p<0.05$ ). In GA- or GAL-infused rats, plasma glucose concentrations were no different from the CON value of $6.94 \pm$ $0.32 \mathrm{mM}$. In addition, packed red blood cell volumes in all five groups were similar, suggesting adequate hydration in the experimental groups. Caloric intakes in the four infused groups are also shown in Table 2. Caloric intakes of GLU and GA rats were not statistically different from one another, but were different from those of SAL or GAL rats. Results were not contrasted with those of CON rats because only estimates of caloric intake of breast-fed rat pups of similar age were available (15) for comparison.

$I G F$ concentrations. When sera and cytosols from CON rats were subjected to acidification, column chromatography, and subsequent IGF-I-RIA and IGF-II-RRA concentration determinations, significant activities of both IGF were present. A representative chromatogram from CON acidified serum is show in Figure 1 where the low mol wt portion (IGF, fractions 32-42) represents approximately $10 \%$ of the total RRA activity assayed, the remainder consisting of a higher mol wt binding protein portion (fractions 20-31).

After a 24-h fast (SAL group), IGF-I and IGF-II concentrations in serum fell to 12 and $24 \%$, respectively, of control values (Table

Table 2. Selected biochemical parameters in 5 groups of 10-d-old rats

\begin{tabular}{|c|c|c|c|c|c|c|c|}
\hline & $(n)$ & $\begin{array}{l}\text { Wt } \\
(\mathrm{g})\end{array}$ & $\begin{array}{l}\text { Age } \\
\text { (d) }\end{array}$ & $\begin{array}{c}\text { Caloric intake } \\
(\mathrm{kcal} / \mathrm{g} / \mathrm{d})\end{array}$ & $\begin{array}{c}\text { Final plasma } \\
\text { glucose } \\
(\mathrm{mmol} / \mathrm{L})\end{array}$ & $\begin{array}{c}\text { Final packed } \\
\text { cell volume } \\
(\%)\end{array}$ & $\begin{array}{l}\text { Total serum } \\
\text { amino acid } \\
\text { concentration } \\
(\mathrm{mM})\end{array}$ \\
\hline $\mathrm{CON}$ & $(15)$ & $21.7 \pm 1.1$ & $10.6 \pm 0.2$ & 0.4 & $6.94 \pm 0.32$ & $36 \pm 1$ & $4.16 \pm 0.35$ \\
\hline SAL & $(7)$ & $21.6 \pm 1.0$ & $10.9 \pm 0.5$ & 0 & $3.78 \pm 0.44^{*}$ & $39 \pm 1$ & $3.17 \pm 0.51$ \\
\hline GLU & (8) & $23.9 \pm 1.1$ & $10.9 \pm 0.5$ & $0.09 \pm 0.01 \dagger$ & $8.22 \pm 0.89 *$ & $37 \pm 1$ & $2.25 \pm 0.33^{*}$ \\
\hline GA & (12) & $22.2 \pm 0.5$ & $10.6 \pm 0.5$ & $0.06 \pm 0.01 \dagger$ & $6.22 \pm 0.28$ & $37 \pm 2$ & $8.12 \pm 1.81^{*}$ \\
\hline GAL & (16) & $22.1 \pm 0.6$ & $10.3 \pm 0.5$ & $0.25 \pm 0.01 \ddagger$ & $6.53 \pm 0.18$ & $34 \pm 2$ & $5.86 \pm 0.70$ \\
\hline
\end{tabular}

$* p<0.05$ from CON.

$\dagger p<0.05$ from SAL or GAL.

$\$ p<0.05$ from SAL, GLU, or GA.

Table 3. Concentrations of IGF-I and IGF-II in acid gel chromatographed specimens

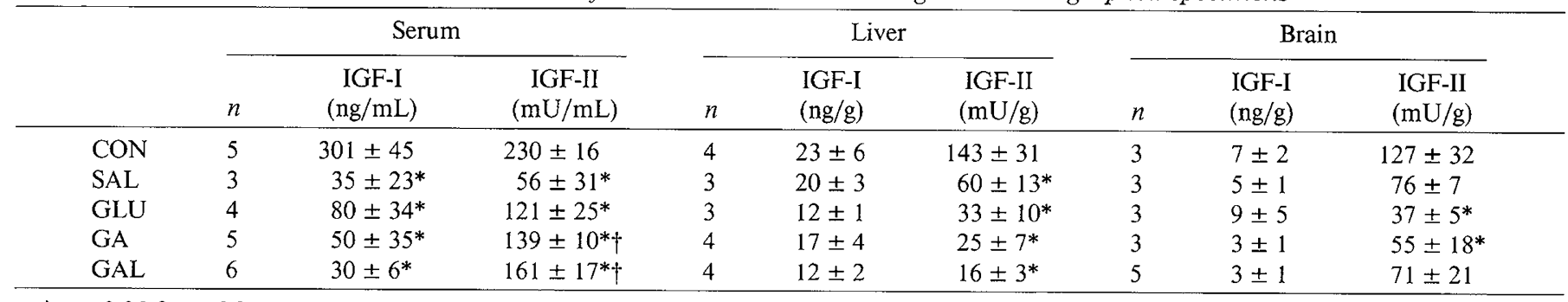

${ }^{*} p<0.05$ from CON.

$\dagger p<0.05$ from SAL. 
3). Intravenous nutrition did not prevent the fall in serum IGFI or IGF-II concentrations. However, serum concentrations of IGF-II were $70 \%$ of control in GAL rats $(p<0.02$ different from SAL rats). When IGF-II concentrations in serum were plotted against caloric intake (Fig. $2 A$ ), a significant linear relationship was observed. However, no relationship between caloric intake and serum IGF-I concentration was noted (Fig. $2 B$ ).

In liver cytosols, fasting (SAL group) induced a decrease in IGF-2 but not IGF-I concentrations (Table 3). No significant differences were noted, however, in IGF-II concentrations between any of the four infusion groups. In brain cytosols, changes similar to those in liver were observed, with decreases in IGF-II but not IGF-I concentration. However, because of interanimal variability, significant changes in IGF-II concentration in brain were noted only in the GLU and GA groups as compared to CON.

IGF-binding protein activity. RRA activity for untreated whole sera and livers and brain cytosols are shown in Table 4. Despite the decreases in IGF-I and -II concentration observed in chromatographed specimens, significant increases in RRA activity were present in both whole sera and liver cytosol samples of all four infused groups when compared to CON rats. However, RRA activities in sera and liver cytosol of GAL rats were significantly decreased from those of SAL rats. No differences in brain cytosol RRA activity were observed among the five groups. When RRA activities in whole sera (Fig. 3) were contrasted with rat caloric intake (assuming a mean control caloric intake of $0.4 \mathrm{cal} /$ $\mathrm{g} / \mathrm{d})(15)$, a significant inverse relationship was present $(r=0.67$, $p<0.01)$. No relationship was apparent, however, between RRA
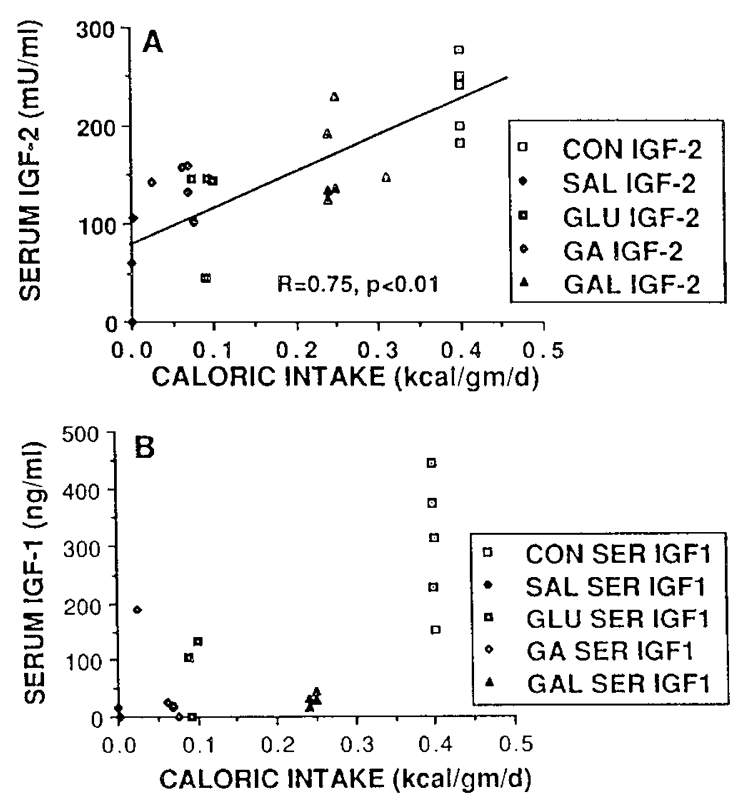

Fig. 2. Concentrations of RRA-IGF-II $(A)$ and RIA-IGF-I $(B)$ in treated sera from all groups related to caloric intake. Caloric intake in CON rats (CON IGF-II) was estimated from Reference 15.

Table 4. RRA-IGF-II activity-untreated specimens

\begin{tabular}{lrccc}
\hline & $n$ & $\begin{array}{c}\text { Whole sera } \\
(\mathrm{U} / \mathrm{mL})\end{array}$ & $\begin{array}{c}\text { Whole liver } \\
\text { cytosol } \\
(\mathrm{U} / \mathrm{g})\end{array}$ & $\begin{array}{c}\text { Whole brain } \\
\text { cytosol } \\
(\mathrm{U} / \mathrm{g})\end{array}$ \\
\hline CON & 15 & $2.0 \pm 0.2$ & $0.7 \pm 0.1$ & $0.7 \pm 0.0$ \\
SAL & 7 & $4.2 \pm 0.8^{*}$ & $4.3 \pm 0.9^{*}$ & $0.7 \pm 0.0$ \\
GLU & 8 & $3.3 \pm 0.6^{*}$ & $3.4 \pm 0.2^{*}$ & $0.7 \pm 0.1$ \\
GA & 12 & $3.3 \pm 0.3^{*}$ & $2.0 \pm 0.3^{*} \dagger$ & $0.7 \pm 0.1$ \\
GAL & 16 & $2.6 \pm 0.2^{*} \dagger$ & $1.3 \pm 0.2^{*} \dagger$ & $0.7 \pm 0.1$ \\
\hline
\end{tabular}

$* p<0.05$ from CON.

$\dagger p<0.05$ from SAL. activity in liver cytosol and caloric intake, but the data suggested a depression of RRA activity in liver cytosol by infusates containing amino acids, irrespective of caloric intake, i.e. RRA activities in livers of GA or GAL rats were significantly different from those in GLU or SAL rats.

Assay of serum amino acids was performed from selected samples in each of the five groups of neonatal rats (Table 2). As can be seen, SAL or GLU rats had total amino acid concentrations $50-75 \%$ of control animals. Decreases in concentration of the majority of amino acids assayed were noted. Total amino acid concentrations in amino acid infused groups (GA or GAL) were at or above control levels. To explore whether or not the RRA activity in neonatal rat serum or liver cytosol was dependent upon circulating amino acid concentration, regression analyses were performed. Although no relationship between total serum amino acid concentrations and serum RRA activity was noted, a highly significant relationship between log total serum amino acid concentration and liver cytosol RRA activity was observed (Fig. 4). In addition, the relationship was similar when the serum concentrations of individual amino acids were studied, specifically those of lysine, serine, arginine, valine, leucine, isoleucine, threonine, and tyrosine.

Characterization of binding protein activity changes. The apparent increase in binding protein activity during fasting was explored further using specimens from rats in control and saline-

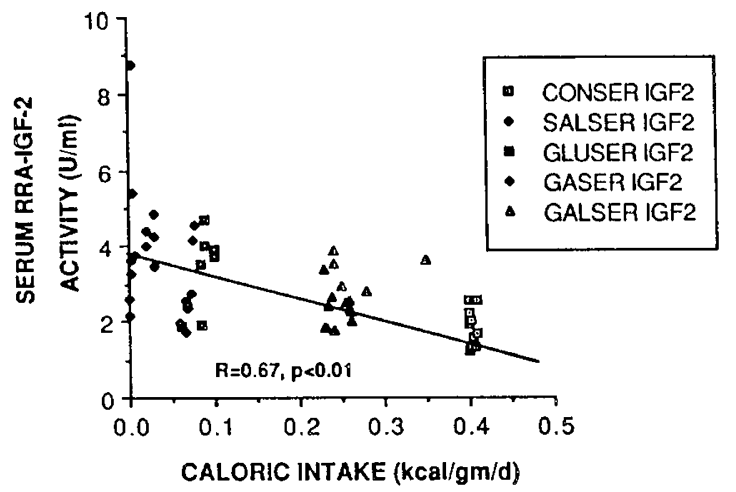

Fig. 3. Whole serum RRA-IGF-II activity related to caloric intake in the five groups of 10 -d-old rats.

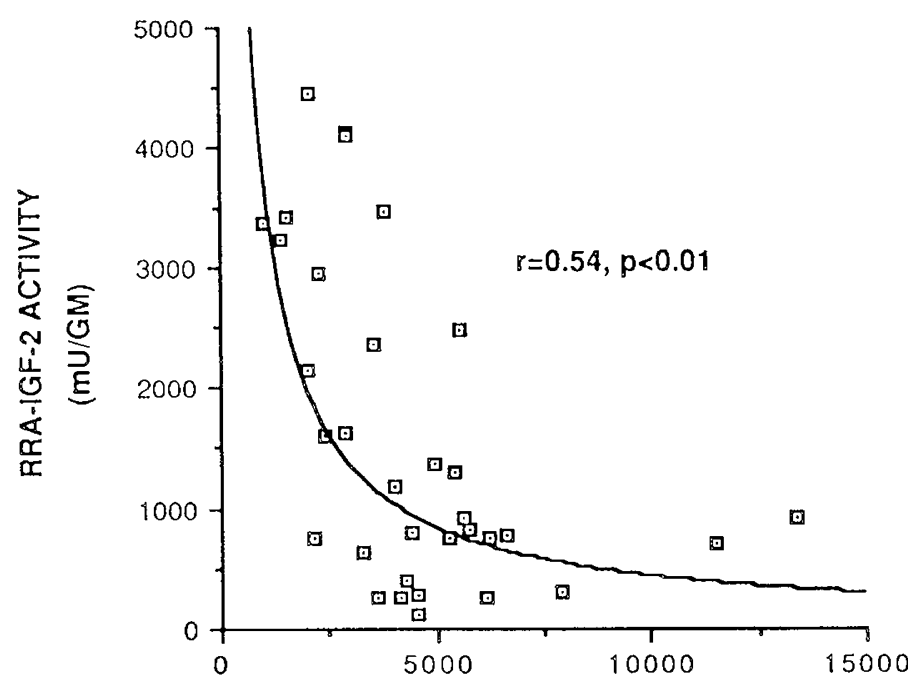

TOTAL AMINO ACID CONCENTRATION

\section{$(\mu \mathrm{M} / \mathrm{L})$}

Fig. 4. Whole liver cytosol RRA-IGF-II activity related to serum total amino acid concentration in the pooled data from the five experimental groups. 
treated groups. Using the RRA-IGF-II assay, RRA activity of control serum or liver cytosol was not changed by the acidification process. In contrast, RRA activity of serum and liver cytosol of saline treated rats was diminished by $50-90 \%$ by the acid treatment. Chromatography of pre- and postacid-treated serum and liver cytosol of saline-treated rats was then performed to test the hypothesis that the apparent rise in binding protein activity during starvation was due to the presence of binding proteins that were either precipitated or destroyed by acid treatment.

Incubation of an aliquot of pooled SAL liver cytosol with purified $\left[{ }^{125} \mathrm{I}\right]$-IGF-II caused a migration of the IGF-II peak to a large mol wt fraction and accounted for $100 \%$ of added radioactivity, consistent with the activity of a binding protein. Prior lyophilization of another aliquot caused only a small decrease in RRA-activity ( $92 \%$ of tracer in large mol wt peak), but acidification of a third aliquot, with subsequent lyophilization, caused a marked $(50 \%)$ reduction in tracer bound to the binding protein peak.
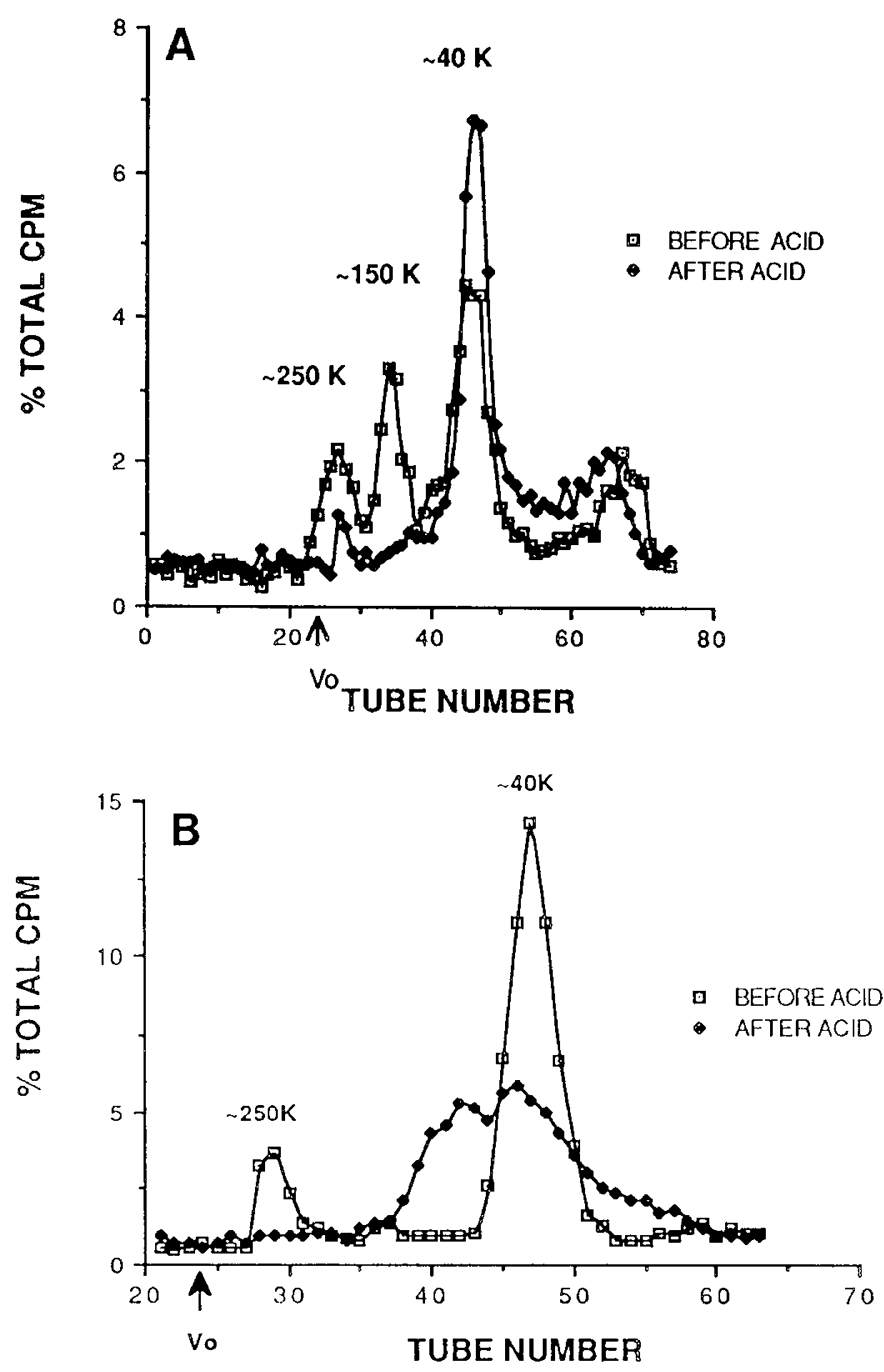

Fig. 5. $A$, gel chromatographs of pooled serum from 10-d-old rats given 24-h saline infusions. Chromatograph in open boxes represents pattern of binding of [ $\left.{ }^{125} \mathrm{I}\right]-\mathrm{IGF}-\mathrm{I}$ to untreated serum. Chromatograph in closed diamonds represents pattern of binding of [ $\left.{ }^{125} \mathrm{I}\right]-\mathrm{IGF}-\mathrm{I}$ to serum previously acidified to $2 \mathrm{M}$, lyophilized, and reconstituted in $50 \mathrm{mM}$ Tris- $0.2 \%$ HSA. B, gel chromatographs of pooled liver cytosol from 10d-old rats given 24-h saline infusions. Chromatograph in open boxes represents pattern of binding of $\left.{ }^{125} \mathrm{I}\right]-\mathrm{IGF}-\mathrm{I}$ to untreated liver cytosol. Chromatograph in closed diamonds represents pattern of binding of $\left[{ }^{125} \mathrm{I}\right]-$ IGF-I to liver cytosol previously acidified to $0.1 \mathrm{M}$ acetic acid, lyophilized, and reconstituted in $50 \mathrm{mM}$ Tris. All chromatographs were performed using G-200 Sephadex with $50 \mathrm{mM}$ Tris- $0.2 \%$ HSA.
To characterize the binding protein changes further, G-200 Sephadex chromatography was applied to SAL rat serum and liver cytosol before and after acidification (as in "Materials and Methods") using two aliquots of each pooled sample. Incubation with [ ${ }^{125}$ I]-IGF-II and subsequent chromatography of the untreated serum sample (Fig. $5 \mathrm{~A}$ ) showed three peaks of binding protein activity, corresponding to mol wt of approximately 40 150 , and $250 \mathrm{kD}$, respectively. Acidification of SAL serum led to a relative decrease in binding activity of the 150 and $250 \mathrm{kD}$ peaks. In liver cytosol of SAL rats (Fig. $5 B$ ), only two peaks at 40 and $250 \mathrm{kD}$ were noted before acid treatment. Acidification caused a shift of radioactivity to the $40 \mathrm{kD}$ peak with a decrease in the $250 \mathrm{kD}$ peak.

\section{DISCUSSION}

IGF (somatomedins) form a class of small mol wt polypeptide hormones with amino acid sequences and cellular metabolic actions similar to those of insulin $(1,2)$. In contrast to insulin, however, at physiologic concentrations, IGF exert potent mitogenic effects on a wide range of cell types such as myoblasts (16), fibroblasts (16), erythroid progenitor cells (17), chondrocytes (18), and oligodendrocytes (19) when tested in vitro. The IGF are ubiquitous, with a large variety of tissue types demonstrated to have the capacity for IGF synthesis and release $(1,2)$. In the adult, control of IGF synthesis, particularly IGF-I, appears due to changes in secretion of $\mathrm{GH}(1,2)$ and, during pregnancy, to changes in the circulating concentrations of the $\mathrm{GH}$ homologue, human placental lactogen $(1,4)$. However, information also exists to suggest that other factors, particularly nutritional intake, may be important in regulating IGF synthesis (20-22).

IGF have recently been shown to be synthesized by a number of cell types in the fetus (23), raising the possibility that IGF may be important in growth regulation during this period of rapid cell division and development. During fetal and early neonatal life, IGF synthesis appears not to be regulated by $\mathrm{GH}(3,8)$. Studies in neonatal rats have also suggested little relationship between somatic growth and GH secretion until after weaning (approximately 21 days) (4). Although not clearly defined in the human, information in laboratory animals such as the rat suggests that the predominant fetal IGF is IGF-II, and that IGF-I concentrations in blood rise only after GH-dependent mechanisms come into play near time of weaning $(3,4)$. Because of adult studies suggesting some relationships between nutrition and IGF synthesis, the current series of experiments were performed in preweanling rats to assess the relationship between nutrition and IGF concentration in perinatal life.

Our studies document that in 10-d-old rats, fasting of 24-h duration caused marked decrements in serum and liver IGF concentrations. Of particular interest is the demonstration that serum IGF-II concentrations were linearly related to caloric intake. However, intravenous nutrition did not raise the concentrations of IGF-I in serum, nor IGF-I or -II in liver or brain cytosols. Only limited information is available regarding the effects of altered nutrition on IGF concentrations during the perinatal period. The results of such studies suggest that nutritional intake is of paramount importance in regulation of IGF-I synthesis. For example, fetal rats made growth retarded via maternal uterine artery ligation have low levels of serum somatomedin activity (24) and of serum and liver RIA-IGF-I concentrations (25) when compared to controls. In addition, RIA-IGFI concentrations were linearly related to fetal wt and fetal serum glucose concentration. The authors could only speculate, however, that deficient substrate transfer to the fetus might be responsible for both depressed IGF synthesis and subsequent growth retardation. No information has previously been available regarding the effects of changes in substrate availability on IGF2 concentrations in the perinatal period. Inasmuch as the predominant fetal and neonatal somatomedin in the rat is IGF-II, the current data provided further evidence for an important role 
for IGF-II in the control of perinatal growth. Synthesis of IGF-I may be more sensitive to sufficiency and quality of caloric intake than IGF-II $(20,21)$, but data from the present study also do not rule out the possibility that stress or hormonal factors related to enteral nutrition may influence IGF-I or -II synthesis, particularly in the liver.

Unlike many classical endocrine hormones, IGF are found in blood and tissue cytosol linked to high affinity binding proteins $(1,2)$. Sites of binding protein synthesis are presently unknown but appear to include a number of cell types including liver (26). In the rat and human, at least several mol wt species of carrier proteins are present in serum. In both adult rat and human, the predominant carrier protein has a mol wt of approximately 150 $\mathrm{kD}$, is altered by acidification, and is under $\mathrm{GH}$ regulation $(1,2$, $26,27)$. Hypopituitary dwarfs and hypophysectomized rats have deficient circulating levels of this carrier protein that can be altered with $\mathrm{GH}$ injection $(26,28)$. The $150 \mathrm{kD}$ binding protein fraction is present in significant quantities in late gestation rat and mouse fetuses. However, in the human and rat fetus, the predominant carrier protein species is a $35-40 \mathrm{kD}$ mol wt protein that is not under GH regulation and appears immunologically distinct from acid generated proteins from the adult $150 \mathrm{kD}$ mol wt species $(28,29)$. A $250 \mathrm{kD}$ mol wt species has also been identified and, in the rat, may be identical to the type II IGF receptor (30). However, regulation of synthesis and release of this protein are not understood.

In our experiments, acute fasting in 10-d-old rats induced marked increases in binding activity, as crudely measured by competition for binding in RRA-IGF-II. Increased binding protein activity using this assay could be due to increases in actual concentration of binding protein(s) but might also be due to changes in binding protein-IGF affinity or receptor site occupancy. The elevations in binding protein activity observed occurred in the face of decreased concentrations of IGF when they were dissociated from their carrier proteins after acidification and gel chromatography. Gel chromatography with G-200 Sephadex demonstrated that the majority of the increased binding activity in the serum and liver cytosol of fasted rats eluted in the fraction of low mol wt IGF binding protein. Interestingly, Sara et al. (31) found paradoxically elevated RIA-IGF-I levels in untreated serum from preweanling rats exposed to pre- and postnatal malnutrition. It is likely that changes in RIA-IGF-I concentration represented similar increases in binding protein activity due to caloric deprivation. Powell et al. (32) have observed increases in IGF binding protein activity in children with chronic renal failure. Increases in concentrations of low mol wt IGF binding proteins have been found in the serum of anorexia nervosa patients (33) and in those with insulin-dependent diabetes mellitus (34), suggesting that intracellular malnutrition may indeed be one causative factor in the generation of IGF binding proteins.

Fasting in 10-d-old rats also induced a marked increase in binding protein activity in liver cytosol. A significant portion of this activity was diminished by acid treatment. Using G-200 Sephadex gel chromatography, an apparent decrease in activity at $250 \mathrm{kD}$ and, perhaps $40 \mathrm{kD}$, mol wt was observed after acid treatment. Whether these changes are due to destruction by acid or precipitation of specific binding proteins is unclear. Ut particular interest is the demonstration that binding protein activity in liver cytosol but not serum was inversely related to circulating amino acid concentrations. It is tempting to speculate that such changes in IGF binding protein concentrations may have been modulated by circulating substrate concentrations, specifically amino acids or by hormonal factors (i.e. insulin) (35) as yet undefined.

The physiologic significance of IGF binding proteins in biologic fluids is not known at present (9). Some investigators have suggested a role for binding proteins as transport proteins to provide dissemination of IGF to sites distant from those of secretion. Because of the high affinity of binding proteins relative to cellular IGF receptors, it has also been suggested that carrier proteins represent either a storage form of IGF or a mechanism for depressing IGF receptor interaction. The current data may be interpreted to suggest that depression of IGF synthesis coupled with the fasting-induced increases in binding protein activity constitute a protective mechanism to inhibit growth during times of caloric deprivation. Furthermore, these studies suggest that nutritional intake is an important factor influencing IGF synthesis in the postnatal period.

Acknowledgments. The authors thank Tracy Lade and Mary Ann Peifer for expert secretarial assistance and Dr. Bo Lindblad for amino acid analysis of serum samples.

\section{REFERENCES}

1. Hall K, Sara VR 1983 Growth and somatomedins. Vitamin Horm 40:175233

2. Froesch ER, Schmid C, Schwander J, Zapf J 1985 Actions of insulin-like growth factors. Annu Rev Physiol 47:443-467

3. D'Ercole AJ 1987 Somatomedins/insulin-like growth factors and fetal growth. J Dev Physiol 9:481-495

4. Sara VR, Hall K 1985 The biosynthesis and regulation of fetal somatomedin In: Gluckman P, Ellendorf F (eds) Fetal Neuroendocrinology. Perinatal Press, New York, pp 213-229

5. Underwood LE, Clemmons DR, Maes M, D'Ercole AJ, Ketelslegers J-M 1986 Regulation of somatomedin-C/insulin-like growth factor-I by nutrients. Hormone Res 24:166-176

6. Adams SO, Nissley SP, Handwerger S, Rechler MM 1983 Developmental patterns of insulin-like growth factor-I and -II synthesis and regulation in rat fibroblasts. Nature 302:150-153

7. Murphy LJ, Bell GI, Duckworth ML, Friesen HG 1987 Identification, characterization, and regulation of a rat complementary deoxyribonucleic acid which encodes insulin-like growth factor-I. Endocrinology 121:684-691

8. Philipps AF, Persson B, Hall K, Lake M, Skottner A, Sanengen T, Sara VR 1988 The effects of biosynthetic insulin-like growth factor-I supplementation on somatic growth, maturation, and erythropoiesis in the neonatal rat. Pediatr Res 23:298-305

9. Daughaday W, Kapadia M, Mariz I 1987 Serum somatomedin binding proteins: physiologic significance and interference in radioligand assay. $\mathbf{J} \mathbf{L a b}$ Clin Med 109:355-363

10. Hall K, Brandt J, Enberg G, Fryklund L 1979 Immunoreactive somatomedin A in human serum. J Clin Endocrinol Metab 48:271-278

11. Marshall RN, Underwood LE, Viona SJ, Foushee DB, Van Wyk JJ 1974 Characterization of the insulin and somatomedin $C$ receptors in human placental cell membranes. J Clin Endocrinol Metab 39:283-292

12. Sara VR, Lazarus L, Stuart MC, King T 1974 Fetal brain growth; selective action by growth hormone. Science 186:446-447

13. Lowry OH, Rosebrough NJ, Farr HL, Randall RJ 1959 Protein measurement with the Folin Phenol reagent. J Biol Chem 193:265-275

14. D'Ercole AJ, Stiles AD, Underwood LE 1984 Tissue concentrations of somatomedin-C: further evidence for multiple sites of synthesis and paracrine or autocine mechanisms of action. Proc Natl Acad Sci USA 81:935-939

15. Keen CL, Lönnerdal B, Clegg M, Hurley LS 1981 Developmental changes in composition of rat milk: trace elements, minerals, protein, carbohydrate and fat. J Nutr 111:226-230

16. Hill DJ, Crace CJ, Strain AJ, Milner RDG 1986 Regulation of amino acid uptake and deoxyribonucleic acid synthesis in isolated human fetal fibroblasts and myoblasts: effect of human placental lactogen, somatomedin-C, multiplication-stimulating activity, and insulin. J Clin Endocrinol Metab 62:753-760

17. Dainiak N, Kreczko S 1985 Interactions of insulin, insulin-like growth factorII, and platelet-derived growth factor in erythropoietic culture. J Clin Invest 76:1237-1242

18. Watanabe N, Rosenfeld RG, Hintz RL, Dollar LA, Smith RL 1985 Characterization of a specific insulin-like growth factor-I/somatomedin-C receptor in high density, primary monolayer cultures of bovine articular chondrocytes: regulation of receptor concentration by somatomedin, insulin and growth hormone. J Endocrinol 107:275-283

19. McMorris FA, Smith TN, DeSalvo S, Furlanetto RW 1987 Insulin-like growth factor-I/somatomedin C: a potent inducer of oligodendrocyte development. Proc Natl Acad Sci USA 82:822-826

20. Prewitt TE, D'Ercole AJ, Switzer BR, Van Wyk JJ 1082 Relationship of serum immunoreactive somatomedin-C to dietary protein and energy in growing rats. J Nutr 112:144-150

21. Pilistine SJ, Moses AC, Munro HN 1984 Placental lactogen administration reverses the effect of low-protein diet on maternal and fetal serum somatomedin levels in the pregnant rat. Proc Natl Acad Sci USA 81:5853-5857

22. Isley WL, Underwood LE, Clemmons DR 1984 Changes in plasma somatomedin- $\mathrm{C}$ in response to ingestion of diets with variable protein and energy content. JPEN 8:407-411

23. Lund PK, Moats-Staats BM, Hynes MA, Simmons JG, Jansen M, D'Ercole AJ, Van Wyk JJ 1986 Somatomedin-C/insulin-like growth factor-I and insulin-like growth factor-II mRNAs in rat fetal and adult tissues. J Biol 
Chem 216:14539-14544

24. De Prins FA, Hill DJ, Fekete M, Robsen DJ, Fieller NRJ, Van Assche FA, Milner RDG 1984 Reduced plasma somatomedin activity and costal cartilage sulfate incorporation activity during experimental growth retardation in the fetal rat. Pediatr Res 18:1100-1104

25. Vileisis RA, D'Ercole AJ 1986 Tissue and serum concentrations of somatomedin-C/insulin-like growth factor-I in fetal rats made growth retarded by uterine artery ligation. Pediatr Res 20:126-130

26. Romanus JA, Terrell JE, Yang YW-H, Nissley SP, Rechler MM 1986 Insulinlike growth factor carrier proteins in neonatal and adult rat serum are immunologically different: demonstration using a new radioimmunoassay for the carrier protein from BRL-3A rat liver cells. Endocrinology 118:17431758

27. D'Ercole AJ, Wilkins JR 1984 Affinity labeled somatomedin-C binding proteins in rat sera. Endocrinology 114:1141-1144

28. Martin JL, Baxter RC 1985 Antibody against acid-stable insulin-like growth factor binding protein detects $150,000 \mathrm{~mol}$ wt growth hormone-dependent complex in human plasma. J Clin Endocrinol Metab 61:799-801

29. White RM, Nissley SP, Short PA, Rechler MM, Fennoy I 1982 Developmental pattern of a serum binding protein for multiplication stimulating activity in the rat. J Clin Invest 69:1239-1252
30. Kiess W, Greenstein LA, White RM, Lee L Rechler MM, Nissley SP 1987 Type II insulin-like growth factor receptor is present in rat serum. Proc Natl Acad Sci USA 84:7720-7724

31. Sara VR, Menolascino S, Sjögren B, Wetterberg L, Muntzing K, Oldfors A Sourander P 1986 The influence of maternal protein deprivation on the developmental pattern of serum immunoreactive insulin-like growth factor I (IGF-I) levels. Acta Physiol Scand 126:391-395

32. Powell DR, Rosenfeld RG, Sperry JB, Baker BK, Hintz RL 1987 Serum concentrations of insulin-like growth factor (IGF)-I, IGF-2 and unsaturated somatomedin carrier proteins in children with chronic renal failure. Am J Kidney Dis 10:287-292

33. Hall K, Lundin G, Povoa G 1988 Serum levels of the low molecular weight form of insulin-like growth factor binding protein in healthy subjects and patients with growth hormone deficiency, acromegaly and anorexia nervosa. Acta Endocrinol (Copenh) 118:321-326

34. Brismar K, Gutniak M, Povoa G, Werner S, Hall K 1988 Insulin regulates the $35 \mathrm{kDa} \mathrm{IGF}$ binding protein in patients with diabetes mellitus. $\mathrm{J}$ Endocrinol Invest 11:599-602

35. Suikkari A-M, Koivisto VA, Rutanen E-M, Yki-Jarvinen H, Karonen S-L, Seppala M 1988 Insulin regulates the serum levels of low mol wt insulin-like growth factor-binding protein. J Clin Endocrinol Metab 66:266-272

\section{Announcement \\ NIH CONSENSUS DEVELOPMENT CONFERENCE: TREATMENT OF DESTRUCTIVE BEHAVIORS IN PERSONS WITH DEVELOPMENTAL DISABILITIES}

A Consensus Development Conference on Treatment of Destructive Behaviors in Persons with Developmental Disabilities will be held in Masur Auditorium in the Warren Grant Magnuson Clinical Center, National Institutes of Health, Bethesda, MD, September 11-13, 1989. This open forum will focus on the various treatments and approaches used to modify or eliminate destructive behaviors in persons with developmental disabilities.

On the first 2 days, experts will present current scientific thinking about the diagnosis, management, and prevention of destructive behaviors in persons with developmental disabilities, and concerned voluntary organizations will be invited to make statements. On the 3 rd day, after considering the scientific evidence, the consensus panel will present its draft report and invite comments from the audience. Dr. R. Rodney Howell, Professor and Chairman, Department of Pediatrics at the University of Miami School of Medicine, will chair the panel.

For further information and registration contact Ms. Barbara McChesney, Prospect Associates, Suite 500, 1801 Rockville Pike, Rockville, MD 20852 (301) 468-6555. 